\title{
PIONEER
}

VOLUME 10, Issue 2, December 2018: 114 - 123

\section{IRONY ANALYSIS OF MEMES ON INSTAGRAM SOCIAL MEDIA}

\author{
Widia Lestari \\ University of Abdurachman Saleh Situbondo \\ widialestari2@gmail.com
}

\begin{abstract}
This study disscused the irony in memes on Instagram. The memes were selected by selecting some accounts on Instagram. The aims of this study are to identify the types of irony in meme and to describe the meaning of irony used in memes on Instagram. In conducting this research, the methodology used is descriptive method by Creswell (2008). Theory of types of irony by Perrine (1966) and theory of meaning by Leech (1981) are used to do the analysis. The result of this research shows that there are twenty six verbal irony and four situational irony. Verbal irony in memes can attract the readers interest, and situational irony gives funny effects because of discrepancy between appearance and reality, or between expectation and fulfillment. Verbal irony and situational irony found on the Instagram are illustrated through the utterances in memes, and these memes have implicit meaning (nonliteral meaning). How the readers understand the memes depends on their culture, time, and individual experience. Besides, the readers can get the meaning of memes if they compare the memes with the topic that has been viral their life.
\end{abstract}

Keywords: irony, memes, instagram

\section{INTRODUCTION}

Human as a social being throughout their life cannot be separated from their social attachment. Human is attachment to other community members requires them to interact and communicate with each other. This requires a proper communication tool. Humans choose language as a mean of communication. In communicating, people sometimes use non-literal meaning rather than literal meaning. Literal meaning uses words exactly according to their conventionally accepted meanings. Non-literal meaning uses words that deviate with the meaning to give a meaning more complicated. Non-literal meaning is also called figurative language.

Figurative language is used this, to express thoughts, feeling, ideas, and also to give an information implicitly not explicitly.There are many types of figurative language they are: simile, irony, metaphor, personification, and so on.

Irony is one part of the figurative language that is often used. An irony in literary work that has a meaning implicitly. Perrine (1966: 225) also said irony is a term with a range of meanings, all of them involving some sort of discrepancy or incongruity and it is a contrast in 
which one term of the contrast in some way mocks the other term.Irony is not only used in literary works but also in daily life. At this time, using the irony in daily life especially among Internet usersis something displayed by using memes. A meme is made to describe something in the current situation happening and based on the fact.Meme is very popular nowadays and it is so viral, it spreads like a virus among internet users.Memes can be found on various social mediasuch as Facebook, Twitter, Instagram, Line and so on. However, Instagram is the most used social media nowdays.

Instagram is an application to share photos or videos video by using filters. Another function of Instagram is for business online, for example, people who have a lot of followers will take advantages of open endorse to make money. That is why Instagram is more preferred because it is so profitable. Based on that, the researcher was conducted this research based on some research problems and objectives. The research problems are what are the types of irony used in memes on Instagram? and what are the meanings of irony used in memes on Instagram? Moreover, the objectives of this study were to identify the types of irony used in memes on Instagram and to describe the meanings of irony used in memes on Instagram.

\section{REVIEW OF LITERATURE}

\section{Figurative Language}

Figurative language is closely related toSemantics because it learns about meanings. A figurative language which uses a figure of speech in a literary work and oral form used in an essay or another thing like lyric and meme that aim to represent the feelings and thought of the author. In another hand, figurative language itself has special meaning of author that the author wants to give to the readers. There are many figurative languages that commonly appear in literary work, there are "metaphor, simile, paradox, symbol, metonymy, personification, synecdoche, allegory, and irony. It depends on which one of the figures of speech that the author wants to choose for his/her works. From the definition of figurative language, it can be concluded that figurative language creates as more interesting literary work.

\section{Irony}

Irony is a kind of figurative language that can make literary works more interesting, attractive, and more descriptive. Because of that, the literary work that consist irony can influence the readers by the style of language to make the readers not bored. Irony is the use of words to convey the opposite of their literal meaning. A statement or situation meaning is contradicted by the appearance or presentation of the idea, Barnet in Maula (2013: 23).Another 
theory of Perrine (1966: 224) also said that irony is a term with a range of meanings, all of them involving some sort of discrepancy or incongruity and it is a contrast in which one term of the contrast in some way mocks the other term.

\section{Types of irony}

1. Verbal Ironyis a figure of speech in wich the opposite is said from what is intended. There is a discrepancy between what is said and what is meant.Thus, the irony is the use of words to express something other than and especially the opposite of the literal meaning. In other words, you say something but actually, it means the opposite.

2. Situational irony is the discrepancy is between appearance and reality, or between expectation and fulfillment, or between what is and what would seem appropriate. In addition, discrepancy between the expected result and actual result. This deals with the unexpected and the incoherent situations. This situational irony is embedded in an environment where the universe seems to be against you, in other words, when we unexpected happens.

3. Dramatic irony is a situations that arise in the drama when a character speaks something that is beneficial to the reader or audience, but is not realized by other characters.

\section{The Goals of Irony}

a. Humor goals: The "clash of values" that occurs in many ironic situations often has two sides, a humorous and a tragic one. Even when injustice or injury is the focal points of the ironical situation, the protagonist, who often is the subject of irony himself, talks about the situation in a humorous way afterward.

b. Social hedging goals: irony is used as a tool to get to know an unknown person and his or her values. When a listener responds to an ironic statement of the speaker (agreement or disagreement), both conversational partners "may establish either a concurrence or discrepancy of values"

c. Instructional goals: Ironic statement with an instructional goal soften the actual intent of the speaker to criticize or to assign. A "gentle ironic comment to inform a child of the rule and indicate the consequences of future violations" could represent a proper example of an instructional goal of an ironic statement.

\section{Semantics}

Semantics is a branch of linguistics that examines meanings.Leech (1981:IX) semantics is central to the study of communication and as communication becomes more and more crucial 
factor in social organization, the need to understand it becomes more pressing. Hence, it is clear that Semantics learn about the meaning and trough language because if you want to learn Semantics deeply, you should know that character of language itself.Yule has two clasifications of Semantics they are conceptual meaning and associative meaning. Conceptual meaning is when alinguists investigates the meaning of words in a language, they are normally interested in characterizing the conceptual meaning and less concerned with the associative or stylistic meaning of words. On the other hands, Leech (1981: 10) also said that conceptual meaning also called denotative meaning is widely assumed to be the central factor in linguistics communication and it can be show to be integral to the essential functioning of language. Associative meaning according to Yule is also called connotations.

\section{Memes}

Meme is an expression of curiosity, expression of entertaining and a meme is one of the phenomena of delivery of messages in a new form. A meme is made to describe something in the current situation is happening and based on the fact. Meme contains pictures and writings. Between the image and writing has an inseparable attachment because if the meme does not has an image it will be a little harder to convey the meaning. The researcher concluded that the transmission of memes in social media is very fast and the memes spread like viruses. Reading memes can accidentally affect a person's life. For example, imitating what is always there in the meme the example of the way the food we eat will be more likely to mimic the meme.

\section{Meaning in Memes}

Meaning in meme has an implicit meaning (non-literal meaning). Implicit meaning is also called connotative meaning because it depends on the culture, time, and individual experience. You will get the meaning if you compare with the current situation or with look at the picture of the meme. Thus, the meaning of memesis related to the picture or the context of the memes.

\section{Instagram}

Instagram is an application for taking and sharing photos and videos to the various other social media by adding digital filters to get good photos. Instagram was created by Kevin Systrom and Mike Krieger, two scholars from Stanford University in the United States and they both launch Instagram in October 2010 Kristo (2015).

\section{METHOD}


Data in this study were utterance and picture containing irony. The data source of this study wasInstagram and the writer directly obtained datafrom someaccounts, they were @meme,@memescenterofficial, @memecenter,@dagelan, @gimme_meme_now, and $@$ memes. The data collection were collected by selecting some accounts whose many followers.Reading the memes in the selected accounts from January to April.Attempting to understand the meaning of the text on memes which contained of irony. Chosing thirty memes and downloaded all of them by using instadownloader.Making a note by giving number of the data and a code of memes.

To analyse the data, Perrine's theory was used in this study by Readingand understanding the thirty memes.Classifying or identfying the memes by the types of irony according to Perrine's theory. Describing the meaning of memes by using theory of Leech (1981) then comparing with the current situation.Drawing a conclusions after analysing the data.

\section{FINDINGS AND DISCUSSION}

\section{Findings}

Irony is a kind of figurative language which has special characteristics, and that is usually used by people in a daily life to express their feelings. There are many authors who use irony in their literary works to make them more interesting, imaginative, and communicative. Perrine (1996) classifies three types of irony, they are verbal irony, situational irony, and dramatic irony. The researcher found verbal irony and situational irony in the thirty memes from the selected accounts.

There are thirty memes found from the selected accounts on Instagram. There were twenty six memes that belong to verbal irony and there were four memes that belong to situational irony. Thus, out of thirty memes found, mostlyare verbal irony. Below is the classification. 
Table 1. The Data Found

\begin{tabular}{ccc}
\hline Types of Irony & Meme Code & Total \\
\hline \multirow{3}{*}{ Verbal Irony } & M1, M2, M3, M4, M5, M6, & \\
& M7, M8, M9, M9, M10, M11, & \multirow{2}{*}{ M12, M13, M14, M15, M16, } \\
& M17, M18, M19, M20, M21, & \\
& M22, M23, M24, M25, M26 & \\
\hline Situational Irony & M27, M28, M29, M30 & 4 \\
\hline Dramatic Irony & & - \\
\hline
\end{tabular}

\section{Examples of the data found:}

1. Verbal Irony

\section{Me: I'm not gonna drink tonight guys. \\ 4 hours later:}

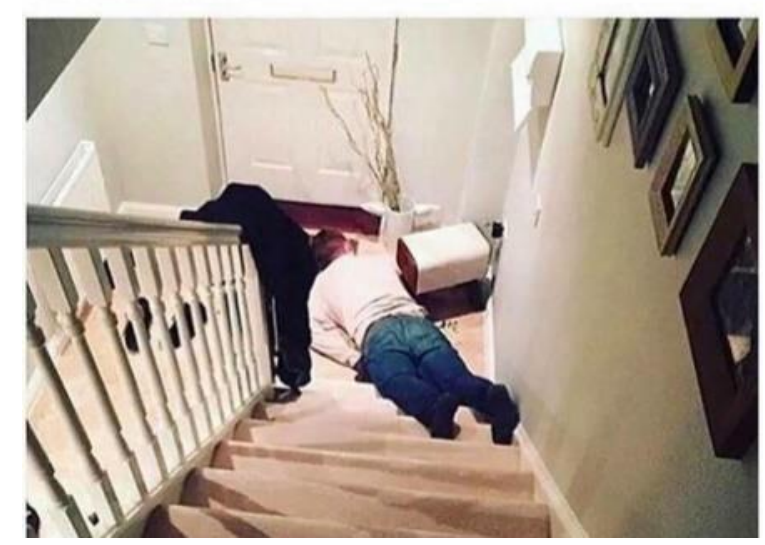

Figure 1. Verbal Irony

Figure 1 shows a man who is lying down on the floor. He is lying down right under the stairs with a messed up room. The utterance of the meme is an irony because it has an implicit meaning. The memes also included in verbal irony because the meme's creator implies the meaning differently from the utterance.

The man on the picture says that he does not want to drink, but four hours later, he is found lying down on the floor because he drank too much. Therefore, it is a verbal irony because what the man says is really contrary to the fact. 
2. Situational Irony

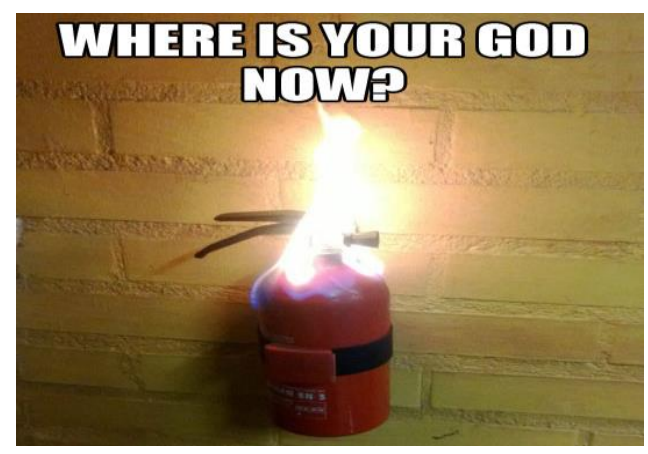

Figure 2 Situational Irony

Figure 2 describes fire hydrant on the wall was on fire. This picture contains irony because there is a meaning implicitly in that picture. The meaning also relates with situational irony and the reason is there is the discrepancy between appearance and reality. If you look at the picture it is a fire hydrant and the function is supposed to put out fires, not catch on fire.

The differences between the result of this study and the previous study they are : In this study, the researcher focused on meme that contained types of irony found in the accounts of Instagram. In the accounts had some forms of meme such as picture and video but the researcher used picture. The researcher chose 30 memes contained irony from the selected accounts since Januari until Aprill 2018. In the process of data analyzing, there are two steps in answering the research problems of this study. Firstly, the researcher found out the types of irony in each meme. Secondly, the researcher described the meaning of irony in that meme.

After accomplishing the study, the researcher found two types of irony related to the classification of irony based on Perrine's theory. The researcher did not find dramatic irony because based theory of Perrine, he explained that dramatic irony is only found in a novel or story. There are twenty six data of verbal irony and four data of situational irony. In addition, the researcher described the meaning of each meme that there is implicit meaning or associative meaning between what it is said and what is trully happened. Those memes took several issues, such as social, pollitics and government. For instance of social issue like M11, the woman said that she would not tell about the man's secret, but in the end she divorced her secret even if only to her friends. This meme showed that what they said is not the same as reality. Another one of government issue is the meme number nine, the meme was made to describe what happened to the government in Ukraine with the aim of criticizing parliamentarians. As members of parliament, they should be able to give good examples to the community by not fighting in the meeting room. But the dominant was a social issue that found from the thirty memes which contained verbal irony. It is because what the researcher found in the thirty of 
memes discussed about social life that contained a humor goals and to tease someone. It often happens in a daily life.

The first previous study was done by Asthereni (2016) entitled An Analysis of Irony in John Grisham's The Rainmaker. In her study, she had three findings : the first finding is discloses how Rudy confronts an experienced lawyer to prove the innocence of his client, which is categorised into exposition, crisis, climax, and resolution. The second finding shows the use of verbal irony in exposition and crisis parts of the story. The situational irony is also potrayed in exposition, crisis, and resolution. The third finding shows that through the use of irony the plot twist could add essential suspense needed by the readers to keep reading the story. The second previous study was done by Puni (2016) entitled The Irony In Searching The Holy Grail In Novel The Da Vinci Code by Dan Brown. In his study, he found three types of irony, they are verbal irony, dramatic irony, and irony of situation are found in the novel. Verbal irony is illustrated through the character of Andre Vernet. Dramatic irony is illustrated through the character's statement of Teacher. Situational irony is illustrated through the character of Aringarosa. The analysis of the placement of irony shows that the irony elements are placed in rising action, climax and resolution. In rising action, the irony found is verbal irony through the character of Andre Vernet. In climax, the irony found is dramatic irony through the characters of The Teacher and Remy. In resolution, the irony found is situational irony through the character of bishop Aringarosa.

After the researcher observed between this study and the previous study, verbal irony was found in a daily life. Besides, verbal irony is also found in the popular issue, for intance politic. Irony found in memes have humor goals, social hedging goals or to tease people and give a criticism. Irony is also very needed because it can make a story or meme very imaginative and interesting to read and not bored.

\section{CONCLUSION AND SUGGESTION}

\section{Conclusion}

After anaysing the data, the researcher concluded that the memes on Instagram from the selected accounts consisted verbal irony and situational irony.Verbal irony and situational irony are potrayed in the utterance that relates to the contex in the memes. Based on the whole of memes that were already analysed, the researcher found twenty six verbal irony and four situational irony. In this research, the types of irony that is often found in the memes is verbal irony because verbal irony is the most dominant types used in a daily life. By using verbal irony and situational irony in memes it can make the memes funny to the readers and make 
the memes interesting to read. In addition, irony in memes which had purposes to entertain and to tease the readers. Thus, using irony in memes influenced the readers by the style of language that make the readers not feel bored.

\section{Suggestion}

Since memes can be very influential to theor readers, the creators of memes should consider what effects the memes they create will make. The creator of memes should avoid creating memes that are socially abusing to particular race, religion, or tribe. On the other side, to understand the meaning of memes, it is also important that the readers have broad knowledge about the current/ongoing issues because by doing so, they can understand the memes easily.

\section{REFERENCES}

Abrams, M.H. (1999). A Glosary of Literary Terms. Seventh Edition. Boston: Earl McPeek.

Arifah, K. (2016). Figurative Language Analysis In Five John Legend's Song (Published Thesis). Malang: Maulana Malik Ibrahim State Islamic University.

Asthereni, P.V.S.Y. (2016). An Analysis of Irony in John Grisham's The Rainmaker (Published Thesis). Yogyakarta: Sanata Dharma University.

Azizah, M.N (2008). Analisis Ironi in Al-Quran (Published Thesis). Yogyakarta: Sunan Kalijaga Islamic University.

Bohang, F.K. (July $7^{\text {th }}$ 2017). Indonesia, Pengguna Instagram Terbesar Se-AsiaPasifik. $\begin{array}{llll}\text { Retrivied June } & 2018 \text { from }\end{array}$ http://tekno.kompas.com/read/2017/7/27/11480087/indonesia-pengguna-instagramterbesar-se-asia-pasific.

Christiansen, H. \& Dahl, V. (2003). Meaning in Context. Roskilde: Computer Science Dept.

Creswell, J.W. (2008). Research Design: Qualitative, Quantitative and Mixed Methods Approaches. (3rd ed). London: SAGE Publications, Inc.

Dawkins, R. (2006). The Selfish Gene. 30th Anniversary Edition. New York: Oxford University Press.

Kemp, S. (January 30 2018). Digital in 2018: World's Internet User Pass The 4 Billion Mark. Retirivied June 20, 2018 from https://wearesocial.com/uk/blog/2018/01/global-digitalreport-2018.

Kreidler, C.W. (1998). Introducing English Semantics. London: Routledge.

Kristo, F.Y. (June 15th 2015). Kevin Systrom, Pencipta Instagram yang Bikin Keder Facebook. Retrivied June 22, 2018 from https://inet.detik.com/cyberlife/d-2942256/kevin-systrompencipta-instagram-yang-bikin-ltigtkederltigt-facebook 
Leech, G. (1981). Semantics The Study of Meaning. Second Edition. London: Penguin Books Ltd.

Maula, M. (2013). An Analysis of Figurative Language on The Poems Entitled "Classic Poetry Series” by William Blake (Published Thesis). Cirebon: English Department of Tarbiyah of the State for Islamic Studies (IAIN) Syekh Nurjati.

Oxford Learner's Pocket Dictionary. (2008). Fourth Edition. Oxford: Oxford University Press.

Perrine, L. (1966). Story and Structure. Second Edition. New York: Harcourt, Brace \& World.

Puni, R. (2016). The Irony in Searching The Holy Grail In Novel The Da Vinci Code by Dan Brown. Manado: Sam Ratulangi University.

Saeed, J.I. (2003). Semantics. Second Edition. Oxford: Blackwell Publishing Ltd.

Simanjuntak, S. (2016). Figuarative Language In Westlife's Second Album Coast To Coast (Published Thesis). Pasir Pengaraian University.

Stanel, T. (2006). An Analysis of British Newspaper Comments. Chemnitz: Technical University Chemnitz.

Yule, G. (1996). The Study of Language. Second Edition. Cambridge: Cambridge University Press. 